\author{
EWA MICHNA \\ (D) https://orcid.org/0000-0003-1547-7621 \\ Uniwersytet Jagielloński \\ Kraków
}

\title{
Emancypacja śląszczyny w kontekście „starych" i „nowych” ideologii językowych
}

\begin{abstract}
Emancipation of Silesian in the context of "old" and "new" linguistic ideologies
Abstract: The emergence of separate nationalities often entails standardisation of the language and an attempt to prove its multifunctional nature, while codification as such becomes one of the basic demands of ethnic movements striving towards emancipation. In her paper, the author analyses the process of emancipation of Silesian in the context of linguistic ideologies, studying above all the ideologies shared by Silesian ethnic leaders. The conclusions presented in the paper are based on analyses of numerous in-depth interviews conducted with Silesian ethnic leaders. This approach makes it possible to take into account, in the analysis of linguistic processes, the point of view of the users of the specific language and their linguistic awareness, and also makes it possible to seek relationships between linguistic awareness, language structure and social phenomena.
\end{abstract}

Key words: Upper Silesia, linguistic ideologies, emancipation, ethnic leaders

Badania emancypacji śląszczyzny ${ }^{1}$ są częścią moich wcześniejszych zainteresowań bezpaństwowymi grupami etnicznymi - Łemkami, Rusinami Karpackimi i Kaszubami. Gdy rozpoczynałam badania Łemków i Rusinów Karpackich, analizowałam działania liderów etnicznych w kontekście procesów narodotwórczych. To sprawiało, że centralnymi kategoriami analizy były pojęcia narodu i nacjonalizmu. Taka perspektywa teoretyczna decydowała

${ }^{1} \mathrm{~W}$ artykule używam zamiennie określeń ślaszczyzna, godka ślaska, jezylk ślaski, pozostając wierna określeniom, których używają moi rozmówcy, zmierzający do emancypacji śląszczyzny i jej oficjalizacji. Zdaję sobie sprawę z różnicy zdań na temat statusu etnolektu śląskiego w dyskursie naukowym, który został szeroko omówiony w wielu publikacjach (Hentschel 2018; Czesak 2015; Kamusella 2008; Tambor 2006; Wyderka 2004). 
też o podejściu do procesów językowych. W myśl tych koncepcji kształtowanie się odrębnych narodowości jest związane ze standaryzacją języka i próbami wprowadzenia go do użycia we wszystkich sferach funkcjonalnych, a kodyfikacja języka jest zwykle jednym z podstawowych postulatów ruchów etnicznych/narodowych zmierzających do emancypacji (Billig 2008, 70-81; Porębski 1991; Chlebowczyk 1983; Hroch 2003; Haugen 1980). W nacjonalistycznym i potocznym dyskursie język często traktowany jest jako podstawowy atrybut narodu (Billig 2008). Na mocy tych przeświadczeń grupa, która chce się odróżnić od innej, dążąca do samookreślenia etnicznego/narodowego, musi udowodnić, że odrębny język posiada. Takie podejście do języka jest jedną z rozpowszechnionych, szczególnie w Europie Środkowo-Wschodniej, językowych ideologii: językowego nacjonalizmu (Wicherkiewicz 2014, 17), czy też ideologii języka standardowego, które obecne w polityce językowej państw, przenikają również do dyskursu akademickiego (Vaicekauskienė 2012). Ideologie te wpływają także na działaczy mniejszości, którzy zmierzają do utworzenia standardu, chcąc zademonstrować, że posiadaja prawdziwy, dojrzały, spójny, język (Eckert 1983; Woolard 1998).

W artykule, rezygnując z perspektywy nacjonalizmu językowego, chciałabym przyjrzeć się procesom emancypacji śląszczyny w kontekście ideologii językowych, podzielanych zarówno przez śląskich liderów etnicznych, zaangażowanych w działania na rzecz uznania odrębności Ślązaków, zabiegających o oficjalizację śląszczyzny, mających wpływ na kreowanie śląskiej polityki językowej, jak i członków grupy, którzy są jej odbiorcami i komentatorami. Kategoria ideologii językowej jest przydatna do analizy wewnątrzgrupowych dyskusji na temat śląszczyzny. Jest także szczególnie bliska antropologicznemu podejściu, które leżało u podstaw prowadzonych przeze mnie badań. Pozwala bowiem na uwzględnianie w analizie procesów językowych perspektywy jego użytkowników i ich świadomości językowej, a także poszukiwanie zależności pomiędzy tą ostatnią a strukturą języka i zjawiskami natury społecznej (Jahns 2010).

Empiryczna podstawą rozważań przedstawionych w artykule są rozmowy z działaczami śląskimi, które prowadzę od 2008 roku. To 90 wywiadów swobodnych $z$ aktywistami śląskich organizacji, liderami etnicznymi podkreślającymi odrębność grupy. Niektórzy z rozmówców to działacze organizacji takich, jak Danga czy Pro Loquela Silesiana, które za główny cel swoich działań przyjęły „piastowanie śląskiej mowy”, ale też wydawcy, dziennikarze, pisarze, blogerzy, działacze zaangażowani w pracę zespołu kodyfikacyjnego języka śląskiego i organizację edukacji regionalnej. Byli to więc zarówno ak- 
torzy procesów emancypacji śląszczyzny, ich aktywni uczestnicy, jak i ci członkowie grupy, którzy tylko te procesy obserwują, komentują, wyrażając opinię na temat podejmowanych działań. Zebrany materiał empiryczny uzupełniają: obserwacja uczestnicząca w imprezach etnicznych, konferencjach, dyskusjach poświęconych godce śląskiej, monitorowanie śląskich stron internetowych oraz portali społecznościowych, które są ważnym miejscem toczącej się debaty o statusie śląszczyzny i pozycji politycznej Śląska (Mętrak 2016), języka jako wyznacznika śląskości, ale są też platformą tworzenia śląskich tekstów i - jak to trafnie nazwał Zbigniew Greń - „standaryzacji żywiołowej” (Greń 2007).

Warto dodać, że ostatnich kilka lat, w trakcie których prowadziłam badania, jest bardzo istotnych z punktu widzenia procesu emancypacji śląszczyzny. W tym czasie podjęto aż cztery próby $(2007,2010,2012,2018)$ wpisania języka śląskiego do Ustany o mniejszościach narodonych $i$ etnicznych oraz o jesyku regionalnym. To okres ważnych działań normalizacyjnych, wydawniczych, edukacyjnych, promocyjnych, w którym pojawiło się wiele inicjatyw na rzecz śląskiej godki. Szczegółowe omówienie czy chociażby wymienienie ich wszystkich tutaj nie jest możliwe. W ciagu kilkunastu lat śląszczyzna przeszła w szybkim tempie drogę od języka funkcjonującego przede wszystkim w życiu prywatnym do języka obsługującego większość dziedzin życia. Namysł nad obecnym stanem godki, w kontekście 14 wymienionych przez Antoniego Furdala sfer funkcjonalnych języka², pozwala na konstatację, że mowa Ślązaków funkcjonuje obecnie w większości wymienionych przez autora sfer funkcjonalnych. Prócz potocznej, która była jej tradycyjną domeną, szkolnej, stowarzyszeniowej, widowiskowej, publicystycznej, religijnej, artystyczno-literackiej, pojawily się także pierwsze próby wprowadzenia języka śląskiego do obiegu naukowego. Obszerną dokumentację i analizę korpusu tekstów śląskich znajdziemy w cennej pracy W spótczesne teksty ślaskie na tle procesów jezyketwórczych $i$ standaryzacyjnych wspótczesnej stowiańszçyzny Artura Czesaka (2015).

\footnotetext{
${ }^{2}$ Furdal wyróżnia 14 sfer funkcjonalnych języka: 1) potoczną - sfera kontaktów towarzyskich, familiarnych, czasem zawodowych; generalnie ustnych; 2) szkolną - na różnych poziomach szkolnictwa; 3) stowarzyszeniowa - zgromadzenia, towarzystwa regionalne i mniejszościowe; 4) informacyjna - informacji masowej (prasa, telewizja, radio) i publiczną (drogowskazy, napisy na środkach komunikacji publicznej, nazwy ulic); 5) widowiskowa - teatr, kino, występy estradowe; 6) usługowa - handel, lecznictwo, poczta; 7) publicystyczna; 8) artystyczno-literacka; 9) kościelna; 10) naukową wyspecjalizowana; 11) administracyjną - regionalne urzędy; 12) sądownicza; 13) reprezentacji zagranicznej - placówki dyplomatyczne; 14) użycia międzynarodowego - kongresy i konferencje (Furdal 1990).
} 
Ideologie językowe - pojęcie używane przez przedstawicieli różnych dyscyplin, przede wszystkim w antropologii, socjolingwistyce i naukach o kulturze (Woolard, Schieffelin 1994) - jest różnorako definiowane. Najszerzej ujmując, obejmują one „postawy, opinie, przekonania lub teorie, które mamy na temat języka” (Ahearn 2013, 33). Według klasycznej definicji Silversteina ideologie językowe to każdy zbiór wyobrażeń o języku formułowany przez użytkowników języka jako racjonalizacja bądź uzasadnienie postrzeganej struktury języka i jego użycia (Silverstein 1979, 193). Ideologie te odnoszą się do języka, jednakże przedstawiają także i sankcjonuja relacje między językiem a tożsamością, estetyka, moralnością i pojmowaniem świata; mają wpływ nie tylko na formy użycia języka, ale też bardziej fundamentalne kwestie społeczne (Woolard 1998; Irvine 19893), są istotne z punktu widzenia takich instytucji społecznych, jak państwo narodowe, system szkolnictwa czy prawo (Woolard, Schieffelin 1994, 56). Paul V. Kroskrity wskazuje cztery istotne cechy charakteryzujące ideologie językowe. Po pierwsze, zdecydowana większość ideologii językowych jest podporządkowana interesom określonych grup społecznych lub kulturowych. Mogą one służyć zarówno do uzasadniania emancypacji językowej grupy, jak i do blokowania aspiracji grup przejawiających takie dążenia. Po drugie, tak jak w każdym konkretnym społeczeństwie istnieją różnorakie podziały i ugrupowania, tak też istnieją różne ideologie językowe. Po trzecie, ludzie mogą być w różnym stopniu świadomi swoich i cudzych ideologii językowych. Po czwarte, ideologie językowe pośredniczą między strukturami społecznymi a formami mowy (Kroskrity 2000). Dwie pierwsze cechy wydają się szczególnie ważne w kontekście podejmowanej w artykule problematyki. Każą one pamiętać, że ideologii językowej nie należy postrzegać jako homogenicznej matrycy kulturowej. Z punktu widzenia działalności rewitalizacyjnej, jak pisze Bartłomiej Chromik (2014), powołując się na Paula Kroskrity’ego (2004), ważne jest osiagnięcie stanu ideologicznego wyjaśnienia (ideological clarification), czyli stanu konsensusu bądź przynajmniej poziomu akceptowalnej różnicy zdań, przez wszystkie strony, których w jakikolwiek sposób dotyczy proces rewitalizacji zagrożonego języka. Stan ideologicznego wyjaśnienia jest ważny, jak sądzę, w przypadku każdej działalności zmierzającej do normalizacji, zachowania i rozwoju języka.

\footnotetext{
${ }^{3}$ Irvine zwraca uwagę, że ideologie językowe odnoszą się do zagadnień szerszych niż sam język, są one bowiem „kulturowym (lub subkulturowym) systemem koncepcji dotyczących stosunków społecznych i językowych wraz z ich obciążeniem interesami moralnymi i politycznymi” (Irvine 1989, 255).
} 
Szczególnie przydatna w kontekście analizy sytuacji śląszczyzny jest też propozycja Nicole Dołowy-Rybińskiej, która analizując sytuację mniejszości językowych w Europie, zwraca uwage, że ideologie językowe wpływają na zachowanie i przekazywanie języka następnym pokoleniom. Jednocześnie uważa, że składające się na ideologie językowe przekonania na temat języka „reprodukują i reprezentują wyobrażenia nadane słabszej grupie przez grupę silniejszą” (Dołowy-Rybińska 2017, 60); nie są one też „»prawdą o języku«, ale »reprezentacją negatywnego stosunku grupy silniejszej do słabszej" (Dołowy-Rybińska 2017, 61). Zawdzięczają więc swą trwałość i skuteczność, działając w taki sposób jak przemoc symboliczna w ujęciu Pierre’a Bourdieu, stając się elementem dominacji (Dołowy-Rybińska 2017). W przypadku działań na rzecz emancypacji, zachowania i rozwoju języka, chcąc by były one skuteczne, zainteresowani muszą dążyć do zmiany ideologii językowych, by przekonania narzucone grupie, że ich język jest gorszy od dominującego, zostały zastapione przez takie przekonania i opinie, które podniosa poczucie wartości własnego języka. Od tego, czy to się uda, zależy też, jak sadzę, powodzenie planowanych działań na rzecz zachowania języka.

W zebranych wypowiedziach na temat śląszczyzny odnalazłam przekonania będące elementem „starych” ideologii - narzuconych przez hegemona, które wyraźnie sytuują język śląski w odniesieniu do innych języków, głównie literackiej polszczyzny, jako mniej rozwinięty, „nie do końca prawdziwy”, „niedojrzały”, co najwyżej in statu nascendi, o nie do końca ustalonym statusie, który nadaje się do użytku tylko w niektórych sferach, jest symbolem zacofania i kojarzony z negatywnie waloryzowaną ,wiejskością”. Ale w większości narracji pojawiły się też przekonania charakterystyczne dla „nowych” ideologii, dowartościowujące język śląski. W niektórych wypowiedziach te „stare” i „nowe” ideologie występują łącznie, sa przedstawiane jako konkurencyjne, „nowe” są odkrywane, konstruowane w dyskursie, w polemice z tymi „starymi”, są reakcją na opinie deprecjonujące śląszczyznę. Oto dłuższa wypowiedź jednego z młodszych aktywistów ilustrująca postawioną tezę:

Kiedy jestem na Śląsku, a czasami nawet poza, wtedy mówię po śląsku i zauważam, jak często ludzie są zdziwieni, zszokowani. Ludzie tutaj. O co chodzi? Jeśli spotkamy na ulicy jakiegoś bezdomnego lub alkoholika i on powie po śląsku „Panie dajcie, dajcie 2 zl”, to wydaje nam się naturalne, do tego przywykliśmy, jakaś taka gwara patologii społecznej. (...) Natomiast jeśli mamy jakieś spotkanie czy jakiś wykład, czy jakieś spotkanie publiczne itd. i nagle pada pytanie zadane po śląsku, to wszyscy się 
odwracaja, wszystkim zapala się taka lampka, że coś jest dziwnego, że (...) to nie jest kod, którego byśmy oczekiwali. Ale ja po prostu mam nadzieję, że jedno, drugie, piętnaste takie spotkanie i ludzie albo sami zaczną mówić, albo zaczną rozumieć, że język śląski może być używany w każdym możliwym kontekście. To po pierwsze, po drugie, że jest na tyle bogaty, że da się nim wyrazić każdą myśl. Także to, że wszystko co można powiedzieć, można powiedzieć po śląsku, a czego nie da się powiedzieć po śląsku, to należy milczeć $(\mathrm{M} / 20-30 / 2018)^{4}$.

Elementy „starych” ideologii czasem występuja jako część postpamięci, sytuowane w przeszłości, jako te charakterystyczne dla poprzedniego pokolenia ukształtowanego w okresie komunizmu, kiedy to godka była deprecjonowana5 . Jednocześnie te „stare” są też często przedstawiane jako balast, który sprawia, że Ślązacy, podobnie jak w minionym okresie, nie chcą mówić po śląsku do swoich dzieci w domu i unikaja godania w sytuacjach publicznych.

Tam jest jeszcze ten wstyd, na terenach wiejskich, że to powinno być w domu, to jest kojarzone z tą wiejskościa, że to jest język wiejski i się go nie przekazuje dzieciom, bo cię na ulicy nazwą wieśniakiem. To szczególnie widać, że matki się bardziej wstydzą mówić do dzieci, to ojcowie raczej mówią do dzieci, a matki bardzo pilnują tego wychowania $(\mathrm{M} / 30$ 40/2011).

To jest wieloletnie, gdzieś wtłoczone w ludziach, że trzeba mówić poprawnie, bo to jest poprawnie, a śląski to jest jakieś takie gorsze, nawet nie gorsze, tylko zniekształcona mowa polska. (...) ale od ostatnich kilku lat to się zmienia, bo ludzie są bardziej świadomi i zaczynają świadomie mówić, też publicznie, po śląsku (M/50-60/2018).

Wiele miejsca w narracjach zajmują też relacje na temat działania szkoły, jednej z głównych instytucji przemocy symbolicznej, która w okresie PRL-u prowadziła politykę językową forsującą upowszechnienie norm literackiej polszczyzny, karząc uczniów, niejednokrotnie fizycznie, za używanie godki.

$4 \mathrm{~W}$ nawiasach podaję: $\mathrm{M} / \mathrm{K}$ - płeć rozmówcy; przedział wieku - 20-30, 30-40, 40-50, $50-60 \ldots$; rok przeprowadzenia wywiadu.

5 O polityce PRL-u wobec zróżnicowań językowych i opinii Ślązaków na temat stosunku państwa do śląszczyzny, traktujących go jako jeden z elementów prześladowań składających się na „śląską krzywdę”, wspominają rozmówcy przedstawicieli różnych dyscyplin, prowadzących badania wśród przedstawicieli ludności autochtonicznej na Śląsku (m.in. Dolińska 2009; Gerlich 2010; Kijonka 2016; Szmeja 2017; Tambor 2006). 
W zebranych narracjach relacje na ten temat występują w dwóch postaciach. W przypadku starszych rozmówców to wspomnienia z dzieciństwa, natomiast w przypadku młodszych pojawiają się jako element postpamięci przekazanej im przez rodziców i dziadków. Według moich informatorów negatywne doświadczenia, a także skutecznie narzucone przekonania na temat niższej wartości własnego kodu, przejmowane przez użytkowników śląszczyzny, sprawiły, że rodzice rezygnowali z używania godki w relacjach z dziećmi.

Pamiętam z dzieciństwa, że kiedy, kiedy ja w dzieciństwie mieszałam oba języki [polski i śląski - E.M.], to babcia poprawiała mnie na poprawne formy polskie. Że się nie mówi np. baba, tylko kobieta.

[Dlaczego? - E.M.] Wtedy to uzasadnione nie było, babcia po prostu mówiła, tak się mówi po polsku, bo pójdziesz do szkoły, to trzeba mówić dobrze. Przypuszczalnie tak, to reminiscencje z dzieciństwa, skoro my swoje wycierpieliśmy za to, że mówiliśmy nie tak jak trzeba, bo jak łapy spuchna, to jednak jest nieprzyjemnie. Nas za śląskie słowa już w szkole nie bito, ale dziadków tak, to siłą rzeczy uważali, że to trzeba oszczędzić te dzieci, skoro wiemy, jak jest poprawnie i możemy poprawić, to lepiej poprawić (M/20-30/2018).

Chociaż rozmówcy podkreślają, że stosunek szkoły do języka śląskiego po transformacji ustrojowej się zmienił, a dzieci nie są już dzisiaj karane za jej używanie, to i dziś uczniowie mówiący po śląsku są traktowani gorzej:

Ważne, żeby rodzice uczyli godki w domu, bo sytuacja na Śląsku jest taka, że do dzieci rodzice mówią po polsku, żeby dzieci nie miały trudności w szkole. Bo dzieci śląskie mają trudno. Nauczyciele, jak [uczniowie E.M.] mówią po śląsku, to mówią im „powiedz to ładnie, powiedz ładnie", to widzi pani, po śląsku znaczy brzydko (K/60-70/2010).

Efekty przekonań składających się na „stare”, deprecjonujące język Ślązaków ideologie, mają ciagle wpływ na używanie śląszczyzny; potwierdza to wypowiedź jednego ze starszych śląskich twórców:

Ja mam wnuków, oni nie mówią po śląsku, czytam im niekiedy swoje wiersze i muszę tłumaczyć i tu nasza wina jest też, bo moja żona godo, a do dzieci się mówi. Jak wnuczka mówi coś po śląsku, to ją poprawia. Nie mówi się godo, tylko godo się mówi (śmiech...). Do naszych też staraliśmy się mówić, żeby nie miały problemów w szkole. Przecież wiem po sobie. Żeby mieć lepiej. Jest takie podejście socjologiczne, że ten co umi 
się wysławiać, to jest coś lepszego. Mówi, to jest coś lepszego, niż ten, co godo. Ja jestem realistą (M/60-70/2010).

Ideologia językowa musi być artykułowana - grupa musi uzyskać pewien stopień językowej świadomości. Analiza wywiadów zebranych w ciagu ostatnich 10 lat wskazuje, że stopień świadomości językowej śląskich liderów etnicznych i wygłaszanych opinii na temat języka się zwiększa. Potwierdzają to także przedstawiane w narracjach językowe biografie badanych, którzy wspominając o sposobie funkcjonowania języka w swoich rodzinach, zwracają uwagę na niewielką świadomość językową swoich rodziców i dziadków, jednocześnie podkreślając, że ich stosunek do języka jest już bardziej refleksyjny. Oto fragment narracji jednego z młodszych rozmówców:

...tego się nie teoretyzowało i nie mówiło się, że to jest konkretny język śląski, czy w inny sposób. Po prostu to był ten swój język, którym się mówiło $\mathrm{w}$ domu $\mathrm{z}$ najbliższym otoczeniem. (...) W rodzinie komunikatywna rola języka jest najważniejsza. Kulturotwórcza, to dopiero później, kiedy w jakimś wieku sobie świadomie zakładasz, żeby w domu, świadomie, używać jedynie języka śląskiego. (...) Nawet wczoraj mama zachęcała mnie do obejrzenia familiady po śląsku, jednak ja skażony już jakimś teoretycznym myśleniem o języku, nie potrafię się z tego śmiać. Mnie to nie bawi, bo zauważam, że to jest takie bardzo spłycanie języka, który dla mnie jest wartością samą w sobie. A nie jest tylko narzędziem komunikacji, jakąś taką dodatkową cechą (M/20-30/2018).

Chociaż ideologia językowa jest tworzona przez użytkowników danego języka, a składające się na nią przekonania moga zmieniać tylko strukturę języka użytkowników, odnosić się może także do innych języków. Rozmówcy mówią o śląskim głównie w relacji do języków: polskiego, niemieckiego, czeskiego. Jednocześnie przekonania o relacji śląszczyzny do języków, w odniesieniu do których sytuują swój język, decydują o strukturze języka, mają bowiem wpływ na to, jak rozmówcy używają języka, a w przypadku tych zaangażowanych w działania normalizacyjne, jakie rozwiązania preferuja. W analizowanych narracjach pojawiają się argumenty: śląski nie jest/nie może być „antypolski”. Oto jedna z tego typu wypowiedzi:

Kiedy staram się napisać jakiś tekst po śląsku, to pierwsze, co robię, to siadam i go piszę tak, jak on mi się układa w głowie (...). Niestety, część śląskiej społeczności robi inaczej, pisze sobie tekst po polsku, a potem wertuje słownik Kallusa i każde słówko podmienia, a jak nie potrafi go 
tam znaleźć, to szuka w słowniku polsko-niemieckim. Żeby broń Boże nie brzmiało to po polsku. Jeżeli tworzymy, tzn. w sensie kodyfikujemy, tworzymy wariant literacki, język śląski, to wolę, żeby to był język śląski, a nie język antypolski, czyli byle nie polski (M/20-30/2018).

Ten sam rozmówca w innym miejscu wywiadu twierdzi, że chociaż jest przeciwnikiem ,germanizowania” śląszczyzny na siłę, powinno się podkreślać różnice w odniesieniu do języka polskiego, bo to ją wyróżnia.

Zgadzam się, że są tendencje, by się od polskiego odróżniać... Zgadzam się i dlatego ja, kiedy piszę po śląsku i mam do wyboru różne formy, z których jedna jest zbieżna z polska, a druga jest zapożyczeniem z języka niemieckiego, raczej będę używał tej niemieckiej, jako czegoś, co nas odróżnia. Natomiast jeśli będę pisał o jakimś zjawisku i w trzech zdaniach z rzędu będę miał to samo słowo, wtenczas użyję raz tego, raz tego. Siła synonimów jest rzeczą wielką w języku. Ale od zapożyczeń niemieckich w tekstach śląskich czasem aż oczy bola. Jest takie szukanie na siłę słów niemieckich (M/20-30/2018).

Narzekania części informatorów, że język niektórych twórców jest „na siłę" germanizowany są jednak równie częste, jak twierdzenia przeciwne - że język śląski powinien zachować jak najbliższe związki z językiem niemieckim. O tym, że śląszczyzna jest przez część użytkowników języka sytuowana blisko niemieckiego, może świadczyć opowieść jednego z moich rozmówców - śląskiego intelektualisty, aktywnie wspierającego procesy emancypacji Ślązaków, który wspominal, że czasem irytuje go, gdy mówiąc, że język śląski należy do grupy języków słowiańskich, widzi rozczarowanie i „musi dyskutować z ignorantami, którzy uważają, że śląski jest językiem germańskim” (M/40-50/2017). To, jak rozmówca sytuuje język śląski wobec innych języków, jest zwykle zależne od tożsamości. Może też mieć wpływ na preferowanie jego konkretnej struktury. Jak twierdzi np. śląski Niemiec Dietmar Brehmer, jednym z powodów nieuznania przez państwo polskie śląszczyzny za język regionalny jest to, że:

koncepcja śląszczyzny jest błędnie skonstruowana, niewyróżniająca istotnie etnolektu śląskiego z języka polskiego. Z całego górnośląskiego kontinuum dialektycznego [chodzi o kontinuum dialektalne - E.M.] - od form skrajnie niemieckich do form skrajnie polskich - wyodrębniono formy polskie. Patriotyzm i polonocentryzm zdominowały koncepcje wniosku, osłabiając z punktu widzenia logistyki - skuteczność osiagnię- 
cia celu (...). Starania o uznanie górnośląskiego etnolektu za język regionalny maja szansę realizacji tylko w przypadku opracowania i przedstawienia go w formie autentycznej i różniącej się naprawdę od języka polskiego (Brehmer 2013, 27).

Część rozmówców, chociaż stosunkowo niewielka, uważa, że mowa Ślązaków jest częścia języka starosłowiańskiego, pozwala to skonstruować granicę pomiędzy polszczyzną a śląszczyzną oraz zbudować często podkreślaną przez rozmówców wspólnotę pomiędzy językiem śląskim a czeszczyzna. Oto jedna z wypowiedzi:

Jeśli bohemista mówi, że to dialekt czeskiego, a polonista mówi, że polskiego, to dla mnie jest to już koronny dowód, że $z$ tym dialektem jest coś nie tak. Bo jeśli ten dialekt da się przypisać do różnych języków, to teza o dialekcie troszeczkę zawodzi. (...) Profesor Miodek i [senator red.] Maria Pańczyk, najpierw zrobili wszystko, żeby znany sobie śląski dialekt wykastrować ze wszystkiego, co nie jest staropolskie, ile się dało wycięli słownictwa niemieckiego, niemieckiej gramatyki, jak już to wszystko wycięli i zstapili słowami staropolskimi, to powiedzieli, to przecież jest staropolszczyzna. Tylko z tymi tezami o staropolszczyźnie jest tak, że jak te stare teksty zobaczył Bralczyk, to powiedział to jest staropolszczyzna, a jak jakiś... nie pamiętam nazwiska, językoznawca z Ostrawy, to powiedział... to jest staroczeski. Problem polega na tym, że to nie ani staropolski, ani staroczeski, ale starosłowiański. Czy on był z Pragi, czy z Poznania, czy z Kalisza, on był prawie taki sam. Tak, że ja bym raczej widział śląski jako język starosłowiański (M/40-50/2010).

Ideologie językowe odnoszą się do postrzeganej struktury i języka, a nie języka jako takiego. Interesująca jest relacja pomiędzy ideologiami językowymi a nauką, głównie koncepcjami językoznawczymi. Nie muszą się one zgadzać z poglądami naukowców dotyczącymi języka (Ahearn 2013, 33), co więcej, teorie naukowe można uznać za pewien rodzaj ideologii językowych (Woolard 1998; Ahearn 2013), zbiór przekonań wypracowany na zewnątrz, przez naukowców, ale dotyczy struktury określonego języka i jego użycia. Jak pokazuje analiza zebranych narracji, te dwa rodzaje ideologii językowych (naukowych i potocznych) przenikają się - koncepcje językoznawcze są dla niektórych z moich informatorów punktem odniesienia, w stosunku do którego uświadamiane i werbalizowane są ich przekonania na temat śląszczyzny.

Rozpocznę od statusu śląszczyzny, kwestii, która dzieli środowisko naukowe. Prawie powszechnie uznawany przez moich rozmówców za podstawę 
tożsamości, odrębności, decydujący o specyfice grupy element kultury, nie ma ustalonego statusu. Przedstawię kilka cytatów, nad którymi chciałabym się zatrzymać, rekonstruując, jakie przekonania użytkowników języka one prezentuja/kryja/ujawniaja, ale też jaki mają związek z wiedzą naukową.

Wszyscy Ślązacy uważający się jednocześnie za Polaków, chociaż było ich w grupie moich informatorów zdecydowanie mniej ${ }^{6}$, uważali, że język śląski to gwara języka polskiego. Takie podejście do śląszczyzny ma też większość uczestników konkursu „Po naszymu, czyli po śląsku”, rozmówców Justyny Kijonki (2016), która konsekwentnie pisze w swej książce o gwarze śląskiej, krytycznie odnosząc się do wszelkich prób emancypacji śląszczyzny.

Ja nie używam język śląski, tylko gwary śląskie, my tu mamy dużo słów staropolskich jeszcze od Reja, Kochanowskiego. Sztuczne dzielenie, Ślązacy zawsze byli Polakami. Ślązak, bo jo godom po śląsku (M/5060/2009).

Ciekawa w przywoływanej wypowiedzi jest, często powtarzająca się również w innych narracjach, fraza o śląskim jako języku staropolskim, języku Reja i Kochanowskiego; to ślad dyskursu naukowego oraz szkolnej edukacji, który wpływa na opinie na temat śląszczyzny podzielane przez moich rozmówców, głównie tych o polskiej tożsamości narodowej. Tego typu stwierdzenia są przedmiotem polemiki wśród zwolenników odrębności językowej Ślązaków, z tezą o staropolskim rodowodzie języka śląskiego dyskutował między innymi przywoływany wcześniej rozmówca, który widział ja jako część języka starosłowiańskiego.

Jednocześnie analiza wypowiedzi liderów organizacji zmierzających do emancypacji, deklarujących odrębność etniczną bądź narodową Ślązaków, wskazuje, że część z nich miała wątpliwości dotyczące statusu śląskiej mowy. Tak myślący często odwoływali się do autorytetu nauki. Ale nie tylko, czasem argumentem jest według nich zbyt duże zróżnicowanie gwarowe, brak standaryzacji, gramatyki, słowników. Dla części z tych rozmówców śląszczyzna jest co najwyżej językiem in statu nascendi.

Język śląski... (długa pauza) język, język regionalny, czyli coś między językiem a dialektem. Ja tu też mam pewien problem, dlatego się trochę waham, bo nie uważam, że język śląski jest językiem w takim znaczeniu

\footnotetext{
${ }^{6}$ Rozmawiałam głównie z działaczami śląskich organizacji, podkreślająch odrębność etniczną/narodową Ślązaków.
} 
jak język rosyjski, francuski czy portugalski. Nie jest, bo moim zdaniem prywatnym, nie ma aż tak wielu cech różniących, ma odrębne słownictwo, ma pewne cechy gramatyczne, ale też wciąż ma tyle podobieństw do polskiego, może to jest wynik tych kilkudziesięciu lat tego przenikania się (M/40-50/2009).

Rozmówca używa tutaj kategorii jezyyk regionalny, która jest określeniem prawnym, używanym w Ustawie o mniejszościach, ale nie jest pojęciem językoznawczym. To efekt wpływu pola, w którym odbywa się dyskusja na temat uznania śląszczyzny, a które jest zdefiniowane przez wspomnianą ustawę. Analiza wywiadów zebranych w różnym okresie długotrwałych badań, wskazuje, że termin jezyyk regionalny pojawia się coraz częściej wraz z kolejnymi próbami oficjalizacji śląszczyzny.

W wypowiedzi pojawia się też porównanie do innych języków „prawdziwych”, „dojrzałych”, „uznanych”, „narodowych” - taka kategoryzacja to echo nacjonalizmu językowego i ideologii języka standardowego, już tutaj wspomnianych. Ostatni fragment przywołanej wypowiedzi odnosi się do podobieństwa śląszczyzny do języka polskiego. Jeśli wykazuje ona cechy wspólne z polszczyzną, to - jak twierdzi część moich informatorów - nie dlatego, że jest częścią języka polskiego, ale dlatego, że jest „spolonizowana”. Przenikanie się obu kodów to, oczywiście, proces złożony, bo to wpływ przybyszów, ale też polskiej szkoły i mass mediów. Według tak myślących polonizacja rozpoczęła się wraz z przyłączeniem Śląska do państwa polskiego.

Inne argumenty padają w rozmowie z młodym śląskim działaczem, który także ma kłopot z jednoznacznym określeniem statusu śląszczyzny:

Gwara, język, jak zwał tak zwał. Ciężko mi właśnie powiedzieć. Ja jestem polonista, to serce mi mówi, że język, a umysł mi mówi, że gwara. Ja chciałbym, żeby to był język, ale naukowe argumenty sa jednoznacznie za gwara. Jest za dużo tych dialektów śląskiego, jest tyle odmian. Wiadomo, w Katowicach się mówi inaczej po śląsku, w Opolu się mówi inaczej, w Cieszynie inaczej. Więc bardzo ciężko by tak skategoryzować te właściwości języka śląskiego, żeby z cała pewnościa powiedzieć, że to język. Może jakiemuś językoznawcy to się uda, nie wiem. Ja z tego, co się nauczyłem na studiach, uważam, że to będzie trudne. Serce chciałoby, żeby to był język (M/20-30/2009).

Zaprezentowany fragment wypowiedzi pokazuje przenikanie do ideologii językowych treści z dyskursu naukowego, jest on w wywiadach przeprowa- 
dzonych ostatnio wyraźniejszy. Nie tylko w przypadku polonistów. Moi rozmówcy coraz częściej odwołują się do autorytetu nauki, by uzasadniać swoje przekonania na temat statusu śląszczyzny, czasem jednak polemizując z naukowymi ustaleniami. Można powiedzieć, że badani liderzy tworza „nową” ideologię w dyskursie z treściami zarówno „starych”, narzuconych grupie przez hegemona, jak i tych tworzonych przez naukę.

Chociaż status śląszczyzny jako odrębnego języka nie jest dla wszystkich oczywisty, większość z liderów organizacji śląskich, z którymi rozmawiałam na początku badań, twierdziła, że ich mowa jest pełnoprawnym językiem, ponieważ są ludzie, którzy uważają go za swój ojczysty język. Czynnikiem decydującym o istnieniu języka jest zatem świadomość jego użytkowników: „Śląski to język, zdecydowanie. O tym decyduje przede wszystkim, że są ludzie, którzy uważają śląski za język, to dlaczego im się to ogranicza” (M/30 40/2009).

W zebranych przez 10 lat narracjach, ale także obserwacjach i analizie dyskusji na Facebooku, można wskazać pewną ewolucję poglądów na temat statusu ślaszczyzny i zmianę ideologii językowej. Coraz więcej aktywistów śląskich jest obecnie przekonanych, że śląszczyzna to odrębny język. Formułując różne argumenty, prócz tych, że odrębność języka wynika ze świadomości użytkowników, sięgają częściej do katalogu cech obiektywnych: odmiennej od języka polskiego składni czy leksyki, będących wynikiem wpływów niemieckich, czeskich; pochodzenia nie od języka staropolskiego, a starosłowiańskiego. Ten ostatni argument pozwala wyznaczyć symboliczna granicę między śląszczyzną a polszczyzną, z której się godka, według większości językoznawców polskich, emancypuje. Najczęściej jednak pojawia się argument, że uznanie danego etnolektu za gwarę, dialekt czy język jest decyzja polityczną.

W narracjach wielu rozmówców spontanicznie pojawiają się elementy polemiki ze stanowiskami polskich językoznawców negujących odrębność śląszczyzny. Przywoływane są także nazwiska naukowców wspierających dążenia emancypacyjne Ślązaków. Na początku moich badań był to najczęściej Tomasz Kamusella, ale w wywiadach późniejszych pojawiają się także Artur Czesak, Jolanta Tambor, Henryk Jaroszewicz czy też Tomasz Wicherkiewicz. Rzadziej Władysław Lubaś czy Bogusław Wyderka, chociaż część moich rozmówców biorących udział w procesach kodyfikacji i dyskusjach na temat statusu śląszczyzny zauważa ewolucję poglądów dwóch ostatnich uczonych, którzy kiedyś byli odrębności śląszczyzny zdecydowanie przeciwni. W wypowiedziach rozmówców widać także chęć „ujęzykowienia” śląsz- 
czyzny, taki postulat postawił w tekście opublikowanym na portalu Wachtyrz.eu wrocławski językoznawca, Henryk Jaroszewicz, wspierający dążenia emancypacyjne Ślązaków (Jaroszewicz 2018). Użycie określenia gwara czy dialekt wielu informatorów oraz aktywnych uczestników forów uznaje za deprecjonujące dla śląszczyzny i aktywnie je zwalcza. Obserwowałam taką burzliwą dyskusję na Facebooku - rozpoczęła się od tego, że jedna z dyskutantek (naukowczyń sprzyjających Ślązakom) użyła określenia gwara śląska. Poniżej przedstawiam tylko fragment dłuższej wymiany zdań:

A: Był Pan z Katowic, który odpowiadał w gwarze, było wiadomo, skąd jest $(\ldots)$.

B: Jakiej gwarze?

A: Śląskiej () (Specjalnie piszę w „w gwarze” - chociaż wiem, że dla Ślązaków jest to język) (...).

B: Nie ma czegoś takiego jak gwara śląska. Może być dialekt albo język, ale nas szlag trafia, jak słyszymy ,gwara”.

Kodyfikacja języka, jak wspominałam, jest jednym z podstawowych postulatów ruchów etnicznych/narodowych zmierzających do emancypacji. Analiza wypowiedzi moich rozmówców wskazuje, że i w tym przypadku nie ma wśród liderów organizacji śląskich zmierzających do emancypacji jednomyślności, chociaż zdecydowana większość rozmówców uważa, że jest ona konieczna. Ale gdy przyjrzeć się argumentom przeciwników i zwolenników kodyfikacji, to okazuje się, że są one pochodną ideologii językowych, także tych wypracowanych na gruncie nauki. Warto przywołać tu poglądy pochodzącego z Tarnowskich Gór Jana Miodka, wypowiadającego się niejednokrotnie na temat statusu mowy Ślązaków, zarówno jako językoznawca i naukowiec, jak i Ślązak. Swój pogląd dotyczący kodyfikacji śląszczyzny wyraził najdosadniej w rozmowie z Teresą Semik w „Dzienniku Zachodnim”:

Proszę ode mnie nie wymagać udowodnienia, że może śląszczyzna jest odrębnym językiem, nie żądać jej kodyfikacji, bo to jest nonsens. (...) nikt tej kodyfikacji nie wykona. Te dążenia są naiwnością połączoną z fanatyzmem. Myślę, że znajdą się językoznawcy gotowi na wszystko. Ja umywam ręce. Jak Piłat. I wątpię w kompetencje historyczno-językowe tych gotowych na wszystko (Miodek 2011).

W wywiadzie, w którym Miodek swe poglądy uzasadnia, korzysta obficie z popartych autorytetem naukowym przekonań „starej” ideologii językowej, 
widzącej śląszczyznę jako język domowy, jedną z gwar języka polskiego, nienadającą się do używania w niektórych dziedzinach życia (urzędowej, religijnej). Próby stosowania jej w tych sferach są według rozmówcy Teresy Semik czymś groteskowym. Przeszkodą w kodyfikacji jest według Miodka duże zróżnicowanie gwarowe śląszczyzny, a sam pomysł kodyfikacji nie ma sensu, bo „myślący Ślązak miał zawsze oficjalną odmianę swojej mowy regionalnej i tą oficjalną odmianą była polszczyzna ogólna” (Miodek 2011). W wywiadzie pojawia się wiele nacechowanych emocjonalnie określeń dyskredytujących próby normalizacji śląszczyzny. Przytoczyłam wypowiedź Miodka z 2011 roku, ponieważ jest ona przez część moich rozmówców przywoływana jako ilustracja niechętnego stosunku polskich naukowców do aspiracji Ślązaków, zakrywającego istotny fakt, że wszystkie procesy kodyfikacji/normalizacji prowadzą do powstania „sztucznego języka”, a mimo to nie kwestionujemy ich w przypadku języków skodyfikowanych odpowiednio dawno i legitymizowanych przez istnienie państwa narodowego. $Z$ twierdzeniami zawartymi w wywiadzie rozmówcy polemizuja, formułując takie opinie na temat godki, które mają potencjał emancypacyjny, dowartościowuja język śląski, jako „normalny”, „pełnoprawny” język.

Miodek uważa, że nie ma języka śląskiego, jest kilkanaście gwar, które nie są godne miana języka, że jest to zróżnicowanie. Ja z tym się nie zgadzam. Po to jest ta kodyfikacja [rozmówca mówi tu o wprowadzeniu zapisu cieszyńskiego - E.M.], która pokazała, że nie jest tak, że da się to jakoś ująć w karby, że nie jest to tak rozczłonkowane, że wystarczy kilka znaków, które odróżnią sposób czytania tego tekstu (M/60-70/2010).

Oczywiście kodyfikacja jest potrzebna, trzeba te słowa wszystkie spisać, bo będą zanikać. Te opory, które są wewnątrz grupy, wynikają z niezrozumienia, czy jakichś zapatrywań ideologicznych - np. profesor Miodek czy [senator - red.] Pańczyk; oni w swoich wypowiedziach często zawierają swoiste nieprawdy, jak np., że część słów się spisze, a część się wyrzuci, czy też będzie się przymuszać polskie dzieci, by się uczyły śląskiego. To są bzdury, ale na takich bzdurach, wiadomo, buduje się swoja pozycję (M/40-50/2009).

Większość aktywistów, z którymi rozmawiałam, uważa, że kodyfikacja jest potrzebna, możliwa i należy ją przeprowadzić:

Jestem jednoznacznie za kodyfikacją, Jestem tego żywym przykładem. Nie mówię, a chcę mówić, chcę się nauczyć. By uczyć, trzeba skodyfiko- 
wać. Bez tego zniknie godka. Już i tak jest za późno na to. To powinno się wydarzyć pół wieku temu (M/40-50/2010).

Jeśli nie skodyfikujemy, jeśli nie będziemy mieć jakichś konkretnych zasad, w obecnych czasach, pełnej informatyzacji, jeżeli przekaz informacyjny jest taki bardzo istotny, to nie możemy pisać fonetycznie, bo tak naprawdę teraz większość osób fonetycznie pisze, to ok, tak też można, ale ta kodyfikacja musi być, żeby za 100, 50 lat, kiedy nie daj Boże ci ludzie wymră, to da się w jakiś sposób zachować. Wtedy nikt nie będzie marudził, że w tej wiosce to się mówiło inaczej. W perspektywie następnych pokoleń to jest ważna kwestia (M/50-60/2009).

Zwolennicy kodyfikacji w bardzo różnorodny sposób uzasadniaja jej konieczność. Ze względu na ograniczenia formalne artykułu tylko je wymienię. Najczęściej rozmówcy wskazywali, że kodyfikacja jest niezbędna, by można było uczyć języka w szkole; by mógł on przetrwać; by został uznany prawnie i mógł korzystać z dotacji państwa; zyskał prestiż; zakończyły się dyskusje, że go nie ma; aby mogła rozwijać się literatura; by ludzie, twórcy wiedzieli, jak pisać; dla przyszłych pokoleń, bo przekaz pokoleniowy w rodzinie zanika i trzeba go uczyć, więc trzeba wiedzieć jak; żeby go wpisać do jakiegoś katalogu języków świata.

Analiza wywiadów pokazuje także, że moi rozmówcy doskonale znają argumenty przeciwników kodyfikacji. Sami, bez moich pytań, spontanicznie wplatali w swoje wypowiedzi elementy polemiki. Podkreślali, że każdy kodyfikowany język jest sztuczny, że każdy kodyfikowany język (także język polski) jest zróżnicowany; że zachowaniu różnorodności gwar śląskich dużo bardziej niż kodyfikacja zagraża globalizacja i oddziaływanie języka większości, które powodują coraz szybsze znikanie śląszczyzny, która, poza niewielkimi enklawami, głównie w obszarach wiejskich, już praktycznie nie istnieje. Analiza porównawcza narracji zebranych w trakcie całego okresu badań wskazuje, że argumentacja pojawiająca się w wywiadach jest coraz bardziej rozbudowana, subtelna, często pojawiają się argumenty z publikacji naukowych, chociaż czasem z błędami lub w nieco uproszczonej formie.

Tylko kilku rozmówców związanych z organizacjami zmierzającymi do emancypacji wyrażało swoje wątpliwości na temat procesów kodyfikacji śląszczyzny. Jeden z tak myślących badanych na pytanie: „Czy jest Pan zwolennikiem kodyfikacji?" odpowiedział:

I tak, i nie. Tak, bo można by go bardziej chronić i dbać o niego, jak jest z językiem kaszubskim. Nie, bo można zabić wiele odmian tego języka, 
co gdzieś tam jest kiepskie. Bo ja widzę różnice, jak się u nas godo, jak się godo w cieszyńskim, a jak w Opolu (M/60-70/2009).

Inną istotną kwestia pojawiająca się w narracjach badanych jest diagnoza sytuacji języka śląskiego. Większość informatorów uważała, że godka, pomimo mody na jej używanie w niektórych środowiskach, zanika.

Język może nie zaniknie jako taki, ale może się zdarzyć, że zostaną tylko takie może nie getta, ale takie wyspy, gdzie można się porozumieć, czyli właśnie te takie w okolicach Rybnika, Chorzów, Piekary, Świętochłowice, Siemianowice, tam, uważam, że to nie zniknie, ale obawiam się, że może to bez wsparcia takiego odgórnego, może to powoli zanikać (M/40 50/2009).

Wśród moich rozmówców byli tacy, choć nieliczni, którzy mówili, że język śląski jest już obecnie językiem martwym, którym w sposób poprawny mówią nieliczni:

Śląski to język, ale to język martwy i tym językiem się już nikt nie posługuje. I nie wiem, czy jego jeszcze się da odrodzić, coraz częściej się obawiam, że nie. Spotkała pani kogoś, kto mówi po śląsku? Ludzie wrzucają pojedyncze śląskie słowa. To tak jakbym ja mówił, że ja z moją sister poszliśmy do cinemy, i twierdził, że mówię po angielsku. Jeśli nawet nie jest martwy, to za 10, 20 lat będzie martwy. Ja jeszcze znam ludzi mówiących po śląsku, ale to są dinozaury. Może nie martwy, może trochę przesadziłem, ale na wymarciu, i jeśli się go szybko nie zacznie w skuteczny sposób lansować, to on wymrze (M/40-50/2009).

Bardzo trafne, $z$ punktu widzenia naukowych ustaleń, są wymieniane przez informatorów przyczyny stopniowego kurczenia się zasięgu śląszczyzny. Badani mówią o: wpływie języka większościowego; osłabieniu przekazu międzypokoleniowego, zwłaszcza w środowiskach miejskich; braku możliwości zastapienia luki w przekazie rodzinnym transmisją instytucjonalna, poprzez nauczanie w szkole (bez tego rozwiązania, według badanych, przetrwanie języka nie będzie możliwe); stosunku członków grupy do języka (gwara, której nie trzeba się uczyć; niski prestiż). Pomimo szeregu inicjatyw podejmowanych w celu propagowania godki, w niektórych środowiskach w dalszym ciągu traktowana jest ona jako swoiste piętno.

Ideologie językowe badanych liderów organizacji śląskich zabiegających o uznanie odrębności własnej grupy to złożony zbiór przekonań na temat 
struktury śląszczyzny i jej użycia. Złożony, ale też silnie heterogeniczny, będący pod wpływem dyskursów naukowych, które mają charakter uprzywilejowany, hegemoniczny i decyduja, jak użytkownicy śląszczyzny, z którymi rozmawiałam, postrzegają własny język. Dominująca narracja, która płynie z centrum, ale też z części wewnątrzgrupowej opozycji (negującej potrzebę emancypacji śląszczyzny), traktuje śląszczyznę jako prosty kod, nienadający się do obsługi niektórych sfer funkcjonowania języka (np. nauki, administracji, religii). Takie przekonania mają istotny wpływ na sposób użytkowania języka, a także potencjał wyraźnie hamujący emancypację. Ten dominujący dyskurs jest istotnym punktem odniesienia dla moich rozmówców zmierzających do emancypacji, którzy dyskutują z obecnymi w tym dyskursie przekonaniami na temat śląszczyzny, jej miejsca w relacji do polszczyzny czy jej statusu. W ramach tej polemiki kształtuje się „nowa” ideologia językowa, zwiększa się świadomość językowa użytkowników. Analiza wypowiedzi śląskich aktywistów potwierdza tezę badaczy, że ideologie językowe są podporządkowane interesom określonych grup społecznych (Ahearn 2013; Irvine 1989; Woolard 1998; Dołowy-Rybińska 2017). Moga one służyć zarówno uzasadnianiu emancypacji językowej grupy, jak i blokowaniu aspiracji grup przejawiających takie dążenia. Moi rozmówcy w większości podzielaja przekonania, które mogłyby wspierać dążenia emancypacyjne. Niepewność w niektórych kwestiach, np. tych dotyczących statusu śląszczyny, jest - jak sądzę - m.in. wynikiem uprzywilejowania dyskursu naukowego. Tego typu stwierdzenia traktowane są przez niektórych informatorów jako „obiektywne”, niepodlegające dyskusji. Chociaż, jak pokazuje analiza zebranych w różnym czasie materiałów, przekonania na temat języka ulegają zmianie, moi rozmówcy coraz częściej odwołuja się do prac tych naukowców, którzy sprzyjają emancypacji śląszczyzny. Ale mimo zmian, zastępowania „starych” ideologii „nowymi”, zakres różnic w opiniach na temat mowy Ślązaków jest bardzo szeroki i obejmuje: status języka, cechy sytuacji socjolingwistycznej; strategie zachowania języka; postulowane działania wobec braku normy (preskryptywizm - puryzm językowy vs. deskryptywizm); liczbę czynnych użytkowników śląszczyzny. Gdyby powrócić do przywołanego na początku pojęcia ideologicznego wyjaśnienia Kroskrity’ego, można zaryzykować twierdzenie, że moi śląscy rozmówcy na początku XXI wieku, w kwestiach dotyczących własnego języka, są nie tylko dalecy od konsensusu, ale nawet poziomu akceptowalnej różnicy zdań. Ma to istotny wpływ nie tylko na procesy ustalania norm, ale i wszelkich działań podejmowanych na rzecz śląszczyzny. 


\section{Literatura}

Ahearn L.M., 2013, Antropologia lingwistyczna. Wprowadzenie, przeł. W. Usakiewicz, Kraków.

Billig M., 2008, Banalny nacjonalizm, przeł. M. Sekerdej, Kraków.

Brehmer D., 2013, Co sqdzq inni. Ankieta, „Fabryka Silesia”, nr 2.

Chlebowczyk J., 1983, O prawie do bytu małych i młodych narodów. Kwestia narodowa i procesy narodotwórcze we wschodniej Europie Środkowej w dobie kapitalizmu od schytku XVIII do poczatku XX w., Warszawa-Kraków.

Chromik B., 2014, Aspekty pojecia ideologie jezykowe istotne z.perspektywy dziatan remitalizacyjnych, „Zeszyty Lużyckie”, nr 48.

Czesak A., 2015, W spótczesne teksty ślaskie na tle procesów jezyleotwórczych i standaryzacyjnych wspótczesnej Stowiańszçyzny, Kraków.

Dolińska K., 2009, Potoczny i ideologiczny poziom doświadczania ślaskości. Ślazacy w poszukiwaniu odrębności?, Wrocław.

Dołowy-Rybińska N., 2017, Niket za nas tego nie zrobi. Praktyki jezylkowe i kulturowe młodych aktywistów mniejszości jezyleonych Europy, Torun.

Eckert P., 1983, The Paradox of National Language Movements, "Journal of Multilingual and Multicultural Development", no. 4.

Furdal A., 1990, Jezylkoznawstwo otwarte, Wrocław.

Gerlich M.G., 2010, „My prawdzimi Górnoślazacy...”. Studium etnologicæne, Katowice.

Greń Z., 2007, Po ślasku w Internecie. Problemy standaryzacï żywiołowej, w: Z polskich studiów slawistycznych, seria XI, Jezykoznawstwo, Warszawa.

Haugen E., 1980, Dialekt, jezyk, naród, przeł. K. Biskupski, w: Głowiński M., red., Jezyłk i społeczeństwo, Warszawa.

Hentschel G., 2018, Ślaski: gwara - dialekt-jezyke? Spojrzenie z zewnatry, w: Tambor J., red., Polonistyka na poczatku XXI wieku. Diagnozy, koncepcje, perspek.tywy, t. 4. Pogranicza, mniejszości, regiony. Etnolingwistyka, Katowice.

Hroch M., 2003, Małe narody Europy: perspektywa historyczna, przeł. Pańko G., Wrocław.

Jahns M., 2010, To nie jest fajka. Alienacja znaczenia jako pryykład ideologii jezykowej, w: Mikołajczyk B., Taborek J., Zabrocki W., red., Jezyk w poznaniu, Poznań.

Jaroszewicz H., 2018, Jezyk - nie dialekt i nie gwara!, Wachtyrz.eu, tekst on-line: https://wach tyrz.eu/dr-hab-henryk-jaroszewicz-jezyk-nie-dialekt-i-nie-gwara/ [dostęp: 3.12.2018].

Kamusella T., 2008, Czy ślasžçyzna jest jezykiem?, w: Tambor J., red., Ślasko godka. Materiały z konferencji „Ślasko godka - jesžcze gwara czy jednak jesyk”. z 30 czerwca 2008 roku, Katowice.

Kijonka J., 2016, Tożsamość wspótczesnych Górnoślazaków. Studium socjologiczne, Katowice.

Kroskrity P., 2004, Language ideology, in: Duranti A., ed., Companion to linguistic anthropology, Oxford.

Mętrak M., 2016, Gwara? Godka? Jezyke? Ślaska tożsamość jezylkowa w mediach elektronicznych, w: Kresa M., red., Młodzi o jezyku regionów, Warszawa.

Silverstein M., 1979, Language Structure and Linguistic Ideology, in: Clyne P., Hanks W.F., Hofbauer C.L., ed., The Elements: A Parasession on Linguistic Units and Levels, Chicago.

Szmeja M., 2017, Ślask bez żmian (?). Ludzie, kultura i spotecznośí Ślaska w perspektywie postkolonialnej, Kraków.

Tambor J., 2006, Mowa Górnoślazaków oraz ich świadomośc jezylkowa i etniczna, Katowice.

Tambor J., red., 2008, Ślasko godka. Materiaty z konferencji „Ślasko godka - jeszcze gwara czy jednak. jezyk" z 30 czerwca 2008 roku, Katowice. 
Wicherkiewicz T., 2014, Regionalne jezyki kolateralne Europy - porównawcze studia praypadków z.polityki jezykowej, Poznań.

Wyderka B., 2004, Jezyke, dialekt czy kreole, w: Nijakowski L., red., Nadciagaja Ślazacy. Czy istnieje narodowośc ślaska?, Warszawa.

Woolard K.A., Schieffelin B.B., 1994, Language Ideology, "Annual Review of Anthropology”.

Woolard K.A., 1998, Language ideology as a field of inquiry, in: Schieffelin B., Woolard K., Kroskrity P., ed., Language ideologies: Practice and theory, New York. 